\title{
PEMANFAATAN MEDIA SOSIAL DAN PENERAPAN SOCIAL MEDIA ANALYTICS (SMA) UNTUK PERPUSTAKAAN DI INDONESIA
}

\author{
Eko Noprianto*) \\ Fakultas Sekolah Pascasarjana Universitas Gadjah Mada, Yogyakarta, Indonesia \\ e-mail: ekonoprianto.az@gmail.com
}

Naskah diterima: 6 April; direvisi: 13 April; disetujui: 20April.

\begin{abstract}
Abstrak
Penenlitian ini bertujuan untuk mengetahui perkembangan pemanfaatan media sosial di perpustakaan, memberikan rancangan untuk penerapan SMA di perpustakaan, serta mengidentifikasi tantangan dalam penerapan SMA di perpustakaan yang ada di Indonesia. Penelitian ini menggunakan metode kualitatif, dengan melakukan kajian literatur terhadap beberapa hasil penelitian tentang pemanfaatan media sosial di perpustakaan. Hasil penelitian menunjukkan bahwa secara umum pemanfaatan media sosial di perpustakaan adalah sebagai media promosi. Selain itu, media sosial juga digunakan sebagai media untuk berbagi informasi, sebagai media komunikasi, dan media sosial juga telah dimanfaatkan sebagai media untuk mempermudah proses layananan sirkulasi. Penelitian ini memberikan rancangan analitik terhadap facebook dan twitter. Pada facebook, terdapat enam bagian yang perlu diperhatikan dalam proses SMA, diantaranya: overview, likes, reach, visits, posts, dan people. Sedangkan untuk twitter hanya meliputi dua bagian saja yaitu tweet activity dan followers. Hasil penelitian juga mengidentifikasi beberapa tantangan yang dihadapi dalam penerapan SMA untuk perpustakaan di Indonesia, diantaranya: penggunaan media sosial yang belum optimal, permasalahan bahasa, volume data, velocity, variety, dan veracity.
\end{abstract}

Kata kunci: Media sosial, social media analytics, tantangan, perpustakaan.

\begin{abstract}
This study aims to determine the development of social media utilization in the library, to provide a design for the application of SMA in the library, and to identify challenges in the application of SMA in libraries in Indonesia. This study uses qualitative methods, by conducting literature review of some research results on the utilization of social media in the library. The results showed that in general the utilization of social media in the library is as a media promotion. In addition, social media is also used as a medium for sharing information, as a medium of communication, and social media has also been used as a medium to facilitate the process of circulation services. This study provides an analytic design of facebook and twitter. On facebook, there are six parts to note in the SMA process, including: overview, likes, reach, visits, posts, and people. As for twitter only includes two parts only tweet activity and followers. The research also identifies some of the challenges faced in implementing SMA for libraries in Indonesia, including: the use of social media that has not been optimal, language problems, data volumes, velocity, variety, and veracity.
\end{abstract}

Keywords: Social media, social media analytics, challenges, library. 


\section{Pendahuluan}

Perkembangan teknologi informasi dan komunikasi (TIK) banyak memberikan fasilitas untuk membangun interaksi, baik itu antar individu, komunitas, maupun institusi. Salah satu produk TIK yang semakin populer pada masyarakat sekarang adalah media sosial, yang bisa dimanfaatkan sebagai media komunikasi antara individu, komunitas, dan institusi. Pada saat ini, media sosial telah menjadi pilihan sebagai alat untuk mencari dan menyebarkan informasi dalam berbagai macam kepentingan, seperti bisnis, hiburan, politik, serta meliputi berbagai kepentingan dalam dunia pendidikan. Salah satu alasan semakin meningkatnya penggunaan media sosial untuk tujuan tersebutadalah peluang untuk menciptakan, menerima, serta menyampaikan pesan/informasi kepada publik sangat mudah dan biaya yang relatif rendah. Selain itu, keadaan masyarakat yang semakin konsumtif terhadap teknologi menjadi peluang besar dalam menyebarkan informasi ataupun mempromosikan bisnis dengan memanfaatkan platform media sosial.

Media sosial didefenisikan sebagai alat (tools) teknologi online yang memungkin penggunanya untuk melakukan komunikasi dengan mudah melalui internet dalam berbagi informasi, seperti teks, audio, video, gambar, podcast, dan komunikasi multimedia lainnya (odewole, 2017). Selain itu media sosial juga didefinisikan sebagai media perantara yang memiliki orientasi sosial, khususnya yang merekam percakapan pengguna dan menyediakan fasilitas untuk berbagi informasi (Pinelli et al., 2015).

Beranjak dari definisi di atas, media sosial merupakan salah satu sumber data yang cukup besar dan bisa digunakan untuk pengambilan sebuah keputusan. Data dalam bentuk teks, gambar, video, dan bentuk lainnya yang terekam oleh media sosial, akan menggambarkan minat, kecenderungan, serta prilaku dari pengguna. Namun, data-data tersebut perlu diolah terlebih dahulu, sehingga menghasilkan suatu pola yang akan membantu dalam pengambilan sebuah keputusan. Disinilah fungsi dari SMA, untuk mengetahui siapa saja yang mengakses media sosial, mengidentifikasi konten yang relevan dengan kebutuhan pengguna, serta mengidentifikasi interaksi dan keterlibatan pengguna (likes, comments, shares, klick) terhadap konten media sosial (Pinelli et al., 2015).
Jika dilihat perpustakaan masa kini, sebagian besar perpustakaan telah menggunakan media sosial baik sebagai sarana promosi perpustakaan, maupun dalam upaya untuk menciptakan ruang interaksi dengan pemustaka. McCallum (2015) menyatakan “...that over $70 \%$ of libraries are using social media tools and 30\% of librarians are posting at least daily".Selanjutnya, seperti yang dicanangkan oleh para ahli dibidang ilmu perpustakaan dan informasi, serta tercantum dalam pasal 14 ayat 3 Undang-Undang Nomor 43 Tahun 2007 Tentang Perpustakaan bahwa "setiap perpustakaan mengembangkan layanan perpustakaan sesuai dengan kemajuan teknologi informasi dan komunikasi". Dengan demikian, penggunaan media sosial adalah bentuk adaptasi layanan perpustakaan terhadap perkembangan TIK.

Selain sebagaisalah satu upaya untuk terus menerus meningkatkan layanan perpustakaan, penggunaan media sosial juga memiliki manfaat yang cukup besar untuk lebih memantapkan keberadaan perpustakaan itu sendiri. Kemanfaatan itu bisa didapatkan dari penerapan SMA untuk perpustakaan dimasa sekarang. Berdasarkan pernyataan tersebut, penulis bermaksud melakukan penelitian dengan judul "Pemanfaatan Social Media dan Penerapan Social Media Analytics untuk Perpustakaan di Indonesia". Khususnya berkaca pada keadaan perpustakaan yang ada di Indonesia dengan menggali berbagai literatur, terutama terhadap hasil penelitian tentang media sosial dalam dunia perpustakaan yang sudah pernah dilakukan oleh peneliti terdahulu.

Rumusan masalah yang diangkat dalam penelitian ini: (i). Bagaimana perkembanganpemanfaatan media sosial pada perpustakaan di Indonesia?; (ii). Rancangan penerapan SMA untuk perpustakaan di Indonesia?; (iii). Apa tantangan dalam penerapan SMA untuk perpustakaan di Indonesia?

Tujuan yang ingin dicapai dalam penelitian ini ialah mengetahui perkembangan dalam pemanfaatan media sosial di perpustakaan khususnya di Indonesia. Sehingga nantinya penulis bisa memberikan rancangan atau usulan untuk penerapan SMApada perpustakaan yang ada di Indonesia. Selanjutnya, penelitian ini mencoba untuk mengidentifikasi tantangan yang perlu dipelajari dalam penerapan SMA dalam dunia perpustakaan Indonesia. 


\section{Tinjauan Pustaka \\ 2.1 Library 2.0}

Di era TIK yang terus mengalami perubahan dengan cepat, banyak perpustakaan mengadopsi konsep web 2.0 sebagai teknologi komunikasi dengan pemustaka, yang memungkinkan perpustakaan dan pemustakanya untuk melakukan komunikasi secara dua arah. Konsep web 2.0 ini dalam dunia perpustakaan lebih dikenal dengan istilah library 2.0, seperti yang dikatakan Wallis (2007) library 2.0 merupakan kombinasi antara web 2.0 dengan perpustakaan untuk memberikan pelayanan lebih baik kepada pemustaka. Pengembangan konsep library 2.0 akan meningkatkan partisipasi pengguna untuk memantapkan layanan perpustakaan itu sendiri. Sudarsono (2010) "Perpustakaan 2.0 merupakan model layanan perpustakaan yang mendorong perubahan berkelanjutan yang berguna dengan mengundang partisipasi pemustaka dalam mencipta serta mengevaluasi, baik layanan fisik maupun virtual. Selain itu perpustakaan 2.0 juga berupaya mencari pemustaka baru dan melayani pemustaka yang sudah ada dengan lebih baik".

Penerapan library 2.0 atau perpustakaan 2.0 akan mengalirkan informasi kepada pemustaka dengan lebih cepat dibanding pelayanan secara tradisional. Merujuk terhadap sebuah istilah yang dipopulerkan oleh Ranganathan yaitu "the library is growing organism", artinya perpustakaan merupakan organisasi yang harus terus berkembang (Sen, 2008). Maka, pengaplikasian konsep library 2.0 merupakan salah satu bukti bahwa perpustakaan terus berupaya melakukan pengembangan terutama dalam pelayanan dan penyajian informasi. Tentunya perubahan ini harus didukung juga dengan kemampuan pustakawan dalam mengoperasikan dan memahami teknologi yang berbasis 2.0. Artinya pengelola perpustakaan (pustakawan) juga harus mengembangkan kemampuan dan kompetensi dirinya sendiri, untuk mengoptimalkan pelayanan perpustakaan berbasis 2.0 tersebut.

Perlu ditegaskan bahwa library 2.0 ini telah menjadi perhatian para peneliti dibidang ilmu perpustakaan dan informasi lebih dari satu dekade yang silam. Hasil penelitian tersebut, bisa dimanfaatkan sebagai rujukan dan panduan dalam mengembangkan konsep library 2.0 secara berkelanjutan. Seperti yang dijelaskan pada bab pendahuluan, beberapa hasil penelitian membuktikan bahwa platform media sosial telah menjadi tren untuk membangun perpustakaan yang berbasis $2.0 \mathrm{di}$ seluruh dunia, dan begitu juga yang terjadi di Indonesia.

\subsection{Media Sosial}

Social Media Research Group (SMRG) menyebutkan bahwa media sosial dipahami sebagai platform berbasis web yang memungkinkan dan memfasilitasi pengguna untuk menghasilkan dan berbagi konten (informasi), dan memungkinkan pengguna berinteraksi secara online dengan pengguna lain (SMRG, 2016). Beberapa peneliti telah menyelidiki penggunaan media sosial di perpustakaan, dari beberapa hasil penelitian terbukti bahwa setiap perpustakan menggunakan jenis media sosial yang berbedabeda, dan jenis yang paling umum digunakan adalah facebook dan twitter.

Seperti penelitian yang dilakukan oleh Hussain (2015) yang bertujuan untuk mengukur sebaran web 2.0 tools yang banyak digunakan di berbagai asosiasi perpustakaan di seluruh dunia, dari penelitian tersebut ditemukan "...that the Web 2.0 tools like Facebook, Twitter and RSS feed, are most popular among library associations, and while linkedin, flikr, blogs, youtube, google+ are less popular it appears to be a powerful tool of web 2.0". McCallum (2015) juga melakukan penelitian tentang pemanfaatan media sosial di perpustakaan, penelitian tersebut menemukan lebih dari $70 \%$ perpustakaan di seluruh dunia telah menggunakan media sosial, dan jenisyang paling banyak digunakan adalah facebook dan twitter.

Dua penelitian yang bertarap internsional tersebut dirasa cukup untuk mengindikasikan bahwa web 2.0 tools yang banyak digunakan adalah facebook dan twitter. Berdasarkan asumsi penulis, pemilihan terhadap jenis media sosial yang digunakan dipengaruhi oleh karakteristik dari media sosial itu sendiri. Facebook memiliki tampilan yang lebih sederhana dan lebih mudah untuk di operasikan menggunakan komputer ataupun mobile. Selain itu, berbagai macam format informasi (seperti video, gambar, dan link) bisa diposting melalui facebook. Berbeda dengan instagram yang lebih dominan terhadap gambar, ataupun youtube yang lebih berfokus pada informasi dalam bentuk video.Maka komunikasi antara perpustakaan dengan pemustaka akan lebih efektif dengan menggunakan facebook.Selain itu, dari dua penelitian tersebut bisa juga dimaknai bahwa beberapa perpustakaan tidak berfokus hanya pada penggunaan facebook atau twitter saja. Untuk memperluas jangkauan layanan yang diberikan, maka perpustakaan 
juga menggunakan web 2.0 tools yang lainnya, seperti youtube, blogs, linkedin, flikr, dan lainlain.

Media sosial memang telah memberikan fasilitas yang cukup untuk berbagi informasi dan pengetahuan. Terlepas dari persoalan tersebut, media sosial bisa digunakan untuk mencapai tujuan yang lebih besar. Sebagaimana diketahui bahwa media sosial merekam jejak dan menyimpan data dari percakapan ataupun komunikasi yang dilakukan menggunakan platform media sosial tersebut. SMRG (2016) data media sosial bisa dijadikan sebagai bahan analisis dan penelitian tentang penggunaan media sosial oleh pemustaka, untuk mendukung pengembangan, implementasi, meninjau dan mengevaluasi layanan perpustakaan. Contohnya adalah meneliti perilaku pengguna media sosial terhadap penyediaan layanan baru, atau menggunakan data media sosial untuk memprediksi kebutuhan pemustaka terhadap informasi. King (2015) data pada media sosial akan membantu perpustakaan untuk mengetahui dampak positif atau respon terhadap apa yang telah diberikan kepada pemustaka melalui media sosial, untuk mencapai hal tersebut harus terlebih dahulu mengetahui dan memahami SMA.

\subsection{Social Media Analytics (SMA)}

Data media sosial semakin banyak digunakan sebagai sumber penelitian untuk berbagai kepentingan, hal ini dikarenakan penggunaan media sosial yang terus menerus mengalami peningkatan. Di era internet, kegiatan pada media sosial merupakan bagian penting dari kegiatan sehari-hari yang dilakukan oleh masyarakat dunia untuk memenuhi kebutuhan sosialnya. Oleh sebab itu, Mangold dan Faulds (2009) merekomendasikan bahwa media sosial harus dianggap sebagai bagian integral dari strategi pemasaran organisasi dan tidak boleh dianggap enteng

\section{Tahapan dalam Social Media Analytics}

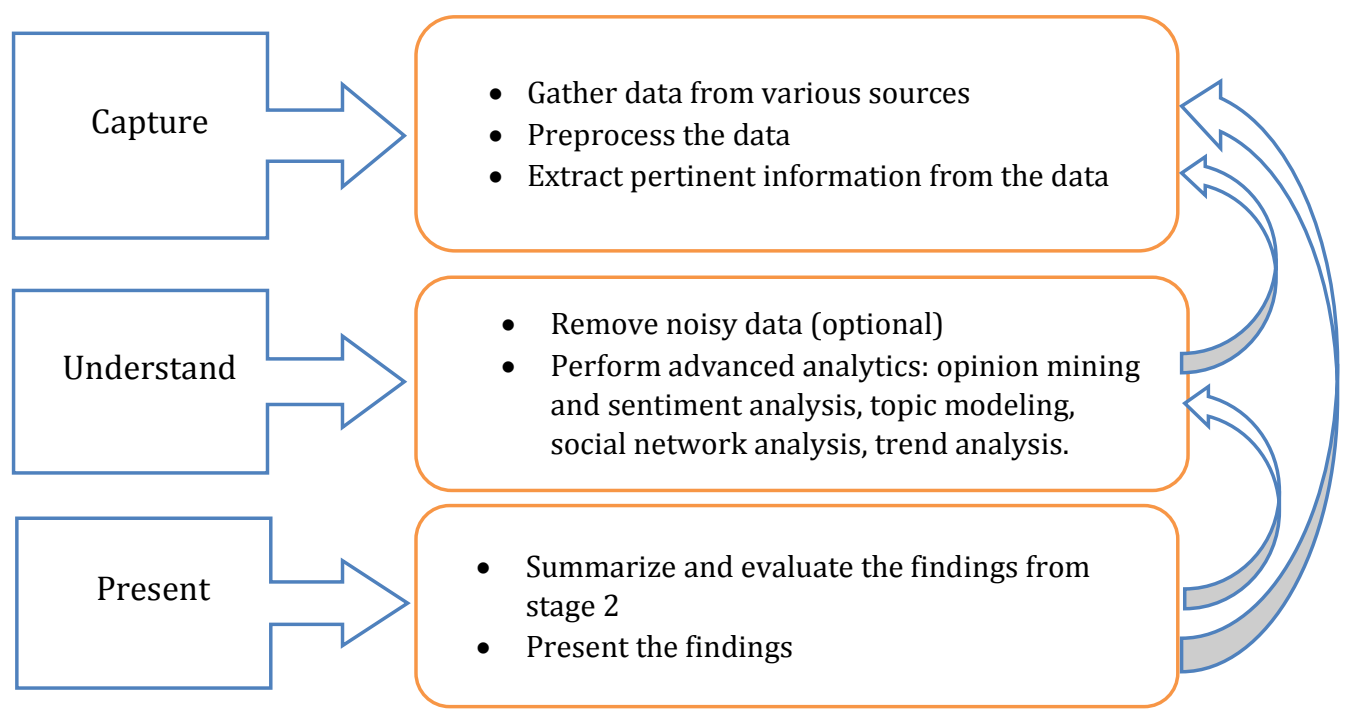


Penetrasi dari data media sosial ini membuka jalan bagi perusahaan, organisasi, dan lembaga seperti perpustakaan untuk memperoleh nilai dan pemahaman tentang kebutuhan dan preferensi pelanggan, mengembangkan layanan, serta memantapkan promosi perpustakaan. Untuk mendapatkan nilai dari data media sosial tersebut, diperlukan penerapan SMA terlebih dahulu.Lovett (2011) mendefinisikan SMA sebagai sebuah metodeanalisis yang membantu perusahaan atau organisasi untuk mengukur, menilai, dan mendiskripsikan kinerja media sosial dalam konteks tujuan yang lebih spesifik. Definisi lain dari Zeng et al (2011) SMA berkaitan dengan pengembangan dan evaluasi alat-alat dan kerangka kerja informatika untuk mengumpulkan, memantau, menganalisis, meringkas, dan memvisualisasikan data media sosial. Fan dan Gordon (2014) merumuskan tiga langkah dalam proses SMA, yang meliputi capture, understand, dan present (Tabel 1).

Capture merupakan proses menghasilkan data media sosial yang relevan melalui monitoring dan listening dari berbagai sumber media sosial, kemudian data tersebut diarsipkan dan mengekstraksi informasi yang saling berkaitan dari data tersebut. Understand memilih data yang relevan untuk pemodelan, menghapus data pengganggu (noisy data) dan data dengan kualitas rendah, dan menggunakan metode analitik data (opinion mining and sentiment analysis, topic modeling, social network analysis, trend analysis J untuk menganalisis dan mengahasilkan wawasan dari data tersebut. Langkah terakhir dari SMA adalah present, yaitu menampilkan temuan dari langkah yang ke dua, setelah data tersebut diringkas dan dievaluasi.

\subsection{Penelitian tentang Media Sosial di Perpustakaan Indonesia \\ Berkaca terhadap beberapa hasil} penelitian tentang media sosial di Indonesia, facebook masih menempati posisi teratas pupuleritas penggunaan platform media sosial. Seperti penelitian terbaru yang dilakukan oleh Sari (2017) tentang pemanfaatan media sosial dalam promosi minat baca anak yang dilakukan oleh Perpustakaan Reading is Fun Jakarta Selatan. Hasil penelitiannya menunjukkan bahwa Perpustakaan Reading is Fun menggunakan media sosial instagram dan facebook untuk mempromosikan perpustakaan dan pentingnya minat baca anak sejak usia dini.
Istiana (2017) melakukan penelitian dengan judul penggunaan media sosial oleh perpustakaan. Ia mengkaji tiga perpustakaan fakultas di lingkungan Universitas Gadjah Mada Yogyakarta, yakni Perpustakaan Fakultas Geografi, Perpustakaan Fakultas ISIPOL, dan Perpustakaan Fakultas Pertanian. Hasil penelitian tersebut menunjukan bahwa perpustakaan menggunakan facebook dengan intensitas yang berbeda. Dari tiga fakultas tersebut, Perpustakaan Fakultas ISIPOL yang paling sering menggunakan facebookdan membuat postingan setiap hari. Selanjutnya, perpustakaan menggunakan facebook untuk mempromosikan koleksi perpustakaan, mempromosikan kegiatan atau layanan perpustakaan, serta menginformasikan berbagai hal yang dianggap penting bagi pengguna, dan menyapa penggunanya.

Penelitian Damayanti (2014) tentang pemanfaatan twitter sebagai media information sharing di perpustakaan. Penelitian ini dilakukan di Perpustakaan Wilayah Kota Surabaya. Dari penelitian tersebut Damayanti menyatakan, twitter memiliki potensi yang besar sebagai media sharing antara perpustakaan dengan penggunanya, karena selalu terhubung dengan internet dan jangkauannya bisa diperluas dengan retweet.

Penelitian Haryanto (2016) yang mengulas tentang media sosial sebagai media yang sangat efektif di jadikan sebagai media komunikasi komunitas pustakawan di perpustakaan perguruan tinggi. Dari penelitian tersebut ia menyatakan bahwa media sosial seperti facebook sangat efektif dipakai sebagai media komunikasi.

Siswanti (2015) melakukan penelitian tentang pemanfaatan layanan perpanjangan masa peminjaman koleksi melalui media sosial facebook. Penelitian dilakukan di Perpustakaan Fisipol UGM yang telah menerapkan sistem peminjaman koleksi melalui facebook. Penelitian dilakukan terhadap data pemustaka layanan perpanjangan melalui facebook pada tahun 2014. Dari penelitian tersebut diketahui bahwa pada tahun 2014 terdapat 4.829 transaksi peminjaman koleksi, dari jumlah tersebut terdapat 3.113 transaksi perpanjangan masa peminjaman. Berdasarkan hasil analisis regresi antara layanan facebook dengan peminjaman manual, Siswanti menyatakan bahwa layanan perpanjangan masa peminjaman koleksi melalui media sosial facebook dapat dikategorikan bermanfaat. 
Anna (2015) meneliti tentang penggunaan web 2.0 sebagai media promosi perpustakaan perguruan tinggi di Indonesia. Penelitian dilakukan terhadap 40 perpustakaan perguruan tinggi di Indonesia, yang telah menggunakan web 2.0 untuk mempromosikan informasi/program/kegiatan di perpustakaan. Dari hasil peneilitian didapatkan bahwa penggunaan web 2.0 yang digunakan oleh perpustakaan antara lain melalui facebook (70\%), twitter (47,5\%), dan RSS feed (35\%), youtube (20\%), instant messenging (20), dan flikr (10\%).

\section{Metode Penelitian}

Medote penelitian merupakan cara ilmiah untuk mendapatkan data dengan tujuan tertentu (Sugiyono, 2012). Maka dalam penelitian ini menggunakan metode kualitatif, dengan melakukan kajian literatur. SulistyoBasuki (2010) menerangkan bahwa kajian literatur adalah memusatkan diri pada pengembangan hipotesis berdasarkan penelitian sebelumnya dan dapat menyarankan penelitian lebih lanjut. Pengumpulan data dilakukan dengan penulusuran berbagai literatur yang berkaitan dengan media sosial dan SMA, terutama hasil penelitian yang sudah pernah dilakukan oleh peneliti terdahulu.

\section{Hasil dan Pemabahasan}

\subsection{Perkembangan dalam Pemanfaatan Media Sosial}

Berdasarkan beberapa penelitian yang telah disajikan di atas, hasil pertama dari kajian literatur ini ialah media sosial telah digunakan diberbagai jenis perpustakaan, akan tetapi penulis belum menemukan adanya penelitian tentang penggunaan media sosial di perpustakaan khusus. Selanjutnya, pemanfaatan media sosial di perpustakaan yang ada di Indonesia pada umumnya masih digunakan sebagai media promosi. Pertama, media sosial digunakan sebagai media untuk mempromosikan minat baca kepada anak sejak usia dini (Sari, 2017). Kedua, media sosial digunakan sebagai media untuk mempromosikan koleksi perpustakaan, kegiatan-kegiatan yang dibuat oleh perpustakaan, serta promosi layanan baru yang akan diterapkan di perpustakaan (Istiana, 2017). Hal menarik dari penelitian Istiana ialah media sosial dimanfaatkan sebagai media untuk menyapa pemustaka, seperti memberikan ucapan selamat tahun baru ataupun ucapan pada saat hari-hari besar keagamaan. Selain itu, melalui media sosial pustakawan juga mengingatkan pemustaka yang masa peminjamannya akan dan telah jatuh tempo.

Hasil kedua dari kajian ini ialah penggunaan media sosial di perpustakaan terus dikembangkan, berdasarkan kebutuhan pemustaka maupun kebutuhan pihak pengelola perpustakaan itu sendiri. Media sosial memiliki potensi yang besar sebagai media information sharing antara perpustakaan dengan penggunanya (Damayanti, 2014), dan media sosial sangat efektif dipakai sebagai media komunikasi (Haryanto, 2016), untuk berbagai kepentingan dalam ruang lingkup perpustakaan. Dari dua hasil penelitian ini dapat dijabarkan, pustakawan atau pengelola perpustakaan diharapkan tidak hanya berfokus pada penggunaan media sosial sebagai penunjang untuk mempromosikan perpustakaan. Pustakawan harus mampu menggali potensi yang ada pada media sosial, sehingga pemanfaatan media sosial tersebut terlaksana dengan maksimal. Era internet telah menyebabkan aliran informasi bergerak dengan cepat dan sangat banyak, mana informasi yang berkualitas dan tidak berkualitas bercampur menjadi satu. Sehingga sebagai orang yang ahli dalam bidang informasi, pustakawan harus bisa mengenali informasi yang berkualitas, dan salah satu cara untuk mempermudah membagikannya kepada pemustaka ialah dengan memanfaatkan media sosial.

Selanjutnya, perpustakaan tidak akan mampu berdiri sendiri hanya dengan memanfaatkan koleksi yang ada. Dengan kata lain, perpustakaan membutuhkan kerjasama dengan perpustakaan yang lainnya, maka ini kembali menuntut pustakawan untuk membangun relasi agar tercipta hubungan kerjasama dengan pustakawan dari lembaga perpustakaan lain. Media sosial memberikan ruang untuk hal tersebut, media sosial bisa digunakan sebagai media komunikasi antara pustakawan, dengan membentuk komunitas atau grup pada media sosial tersebut. Misalnya dengan membentuk komunitas pustakawan dari perpustakaan yang sejenis. Sehingga dalam komunitas tersebut bisa saling berbagi informasi tentang koleksi buku terbaru atau buku-buku yang dibutuhkan pemustaka, serta kepentingan yang lainnya.

Berbeda lagi dengan penelitian Siswanti (2015) bahwa media sosial juga telah dimanfaatkan sebagai media dalam layanan sirkulasi. Pemustaka bisa melakukan perpanjangan masa peminjamannya melalui media sosial, tentunya ini termasuk inovasi baru 
dalam proses pelayanan perpustakaan di Indonesia.

Hasil ketiga dari kajian literatur ini ialah sebagian besar objek penelitian tentang media sosial di Indonesia adalah facebook. Hal ini menggambarkan bahwa perpustakaan di Indonesia lebih tertarik untuk menggunakan facebook dibanding jenis media sosial lainnya. Pernyataan ini diperkuat oleh hasil penelitian Anna (2015) dimana 70\% dari perpustakaan yang ditelitinya adalah menggunakan facebook. Selain itu, sebagian perpustakaan di Indonesia juga telah memanfaatkan berbagai jenis media sosial seperti twitter, RSS feed, youtube, instant messenging, dan flikr. Namun perlu ditegaskan, dalam memilih jenis media sosial yang akan digunakan, sebaiknya perpustakaan mengetahui atau memetakaan jenis-jenis media sosial yang digunakan oleh pemustakanya. Hal ini bisa dilakukan dengan mendata media sosial yang dimiliki oleh pemustaka, ketika mendaftar untuk menjadi anggota baru di perpustakaan.

\subsection{Rancangan untuk Penerapan SMA}

Jenis-jenis analitik yang bisa digunakan untuk setiap jenis media sosial sangat berbedabeda (King, 2015), maka pada bagain ini penulis akan mendalami jenis media sosial yang banyak digunakan di perpustakaan seluruh Indonesia, yaitu facebook dan twitter. Mengacu kepada pendapat King (2015), terdapat enam bagian yang perlu diperhatikan dalam proses SMA, diantaranya: overview, likes, reach, visits, posts, dan people.

Overview. Bagian ini bertujuan untuk mengetahui sekilas gambaran tentang aktivitas yang terjadi di halaman facebook perpustakaan dalam jangka waktu tertentu. Hal yang perlu diperhatikan yaitu jumlah likes (suka), reach (jangkauan), dan engagement (keterlibatan) pengguna terhadap konten yang diposting pada halaman facebook. Selain itu, halaman facebook yang dimiliki oleh sebuah perpustakaan perlu dibandingkan dengan halaman facebook perpustakaan lain (utamakan perpustakaan yang sejenis). Hal ini bertujuan untuk mengetahui tren yang sedang terjadi, dan yang terpenting untuk mempelajari bagaimana perpustakaan lain melayani pemustakanya melalui media sosial.

Likes. Pada bagian ini bertujuan untuk mengetahui pertumbuhan likes (suka) di halaman facebook perpustakaan. Pada bagian ini memerlukan peninjauan secara berkala, apakah dilakukan setiap minggu atau setiap bulan. Hindari untuk meninjau pertumbuhan likes dalam jangka tahunan, karena informasi pada saat ini cepat berkembang dan tentunya kebutuhan informasi pengguna juga akan mengalami perubahan. Informasi yang up to date akan berpengaruh untuk meningkatkan jumlah likes halaman facebook perpustakaan. Oleh sebab itu, pada bagian pertama (overview) dianjurkan untuk membuat perbandingan dengan halaman faceook perpustakaan lain.

Reach. Pada bagian ini akan menunjukan orang yang dijangkau oleh halaman facebook perpustakaan. Hal ini akan diketahui dari jumlah likes, comments, dan shares pada setiap postingan.

Visits. Bagian ini akan menunjukan jumlah orang yang mengakses halaman facebook perpustakaan, berapa kali satu orang melakukan akses, dan berapa lama waktu yang dihabiskan. Seperti penelitian yang dilakukan oleh Larasati (.n.d) tentang pemanfaatan facebook di Perpustakaan Kabupaten Sidoarjo, ditemukan bahwa "pengguna mengakses facebook perpustakaan Kabupaten Sidoarjo 1-2 kali dalam seminggu dengan waktu kurang dari 30 menit. Aktivitas yang dilakukan pengguna saat mengakses facebook perpustakaan Kabupaten Sidoarjo adalah membaca informasi yang diposting oleh perpustakaan".

Posts. Dari postingan yang dilakukan setiap hari pada halaman facebook, akan menjadi informasi bermanfaat jika dilakukan analitik data. Postingan tersebut akan menunjukkan kapan pengguna mengakses halaman facebook perpustakaan, hal ini terkait dengan hari apa dan jam berapa aktivitas yang paling banyak dilakukan pengguna pada halaman facebook perpustakaan. Jika dua hal tersebut sudah teridentifikasi, maka waktu tersebut adalah waktu yang tepat untuk melakukan postingan sehingga pengguna yang dijangkau juga akan lebih banyak.

People. Bagian ini akan menggambarkan demografi pengguna yang mengakses halaman facebook perpustakaan seperti jenis kelamin, usia, serta memberikan rincian pengguna berdasarkan negara, kota, dan bahasa.

Selanjutnya, terdapat dua bagian yang perlu diperhatikan dalam proses SMA (King, 2015), yang meliputi: Tweet activity. Bagian ini akan menyajikan grafik tweet selama sebulan terakhir. Dari setiap tweet akan terlihat impresi, keterlibatan, dan rasio keterlibatan pengguna.Followers. Bagian ini memberikan beberapa wawasan tentang pengikut twitter perpustakaan. Ini menunjukkan berapa banyak 
pengikut yang dimiliki dan menggambarkan minat pengguna (misalnya, tertarik pada buku, berita, komedi, dll.), lokasi pengguna (kota dan negara), dan jenis kelamin pengguna.

\subsection{Teknik Utama SMA}

SMA merupakan area yang berkembang yang mencakup berbagai teknik pemodelan dan analisis dari berbagai bidang. Teknik utama dari SMA ialah opinion mining and sentiment analysis, topic modeling, social network analysis, trend analysis [lihat gambar 1].

Opinion mining and sentiment analysis ini memanfaatkan bahasa komputasional, pemrosesan bahasa alami, dan metode analitik teks lainnya, dan secara otomatis mengekstrak sentimen atau opini pengguna terhadap konten media sosial. Topic modelingdigunakan untuk mendeteksi tema atau topik dominan dari kumpulan teks yang diambil dari platform media sosial (misalnya facebook, twitter, instagram, dll.), artikel berita, dan perilaku pengguna.Social network analysis digunakan untuk menganalisis grafik jaringan sosial untuk memahami struktur dasarnya, hubungannya, dan properti teoretis serta untuk mengidentifikasi kepentingan relatif dari berbagai node dalam jaringan. Trend analysisdigunakan untuk mengidentifikasi dan memprediksi kejadian dimasa yang akan datang berdasarkan historis data yang dikumpulkan dari waktu ke waktu. Penerapan trend analysis termasuk memperkirakan pertumbuhan pengguna, memprediksi keefektifan layanan dengan menggunakan media sosial.

\subsection{Tantangan dalam Penerapan SMA}

Tantangan dalam menerapkan SMA untuk perpustakaan di Indonesia adalah menumbuhkan kesadaran terhadap besarnya peran media sosial dalam meningkatkan kualitas pelayanan perpustakaan. Dengan kata lain, penggunaan media sosial harus dioptimalkan terlebih dahulu. Faktanya, penelitian Anna (2015) menyatakan "diantara perpustakaan yang telah menggunakan media sosial, sebagian perpustakaan masih kurang serius dalam memanfaatkannya, dan sebagian sudah sangat aktif dalam menggunakan media sosial untuk mempromosikan perpustakaan". Begitu juga dengan apa yang dikatakan Kurniasih (2015) "Masih sedikitnya perpustakaan yang menggunakan media sosial yang telah dibuatnya secara aktif, menjadi salah satu bukti bahwa masih banyak perpustakaan yang hanya memiliki akun di media sosial, tetapi belum dipergunakan secara optimal".
Kurniasih (2015) juga menjelaskan, faktor-faktor yang diperlukan agar perpustakaan optimal di media sosial, diantaranya: harus ada dukungan manajemen, kualifikasi pustakawan, orientasi pengguna, sumber informasi, dan aktivitas di media sosial yang harus rutin dilakukan oleh perpustakaan serta memperhatikan strategi-strategi dalam memposting informasi agar mendapatkan respon yang baik dari pengguna.

Terlepas dari penjelasan dari paragraf di atas, berikut beberapa kutipan terkait tantangan secara umum dalam proses SMA yang diambil dari beberapa hasil penelitian yang sudah pernah dilakukan oleh peneliti terdahulu. Pertama, volume data menyulitkan untuk menemukan topik yang relevan, tren, dan event dalam komunikasi media sosial yang dinamis (Kisiviswanathan et al., 2011). Kedua, Data yang dihasilkan dari media media sosial tidak lengkap atau noisy, sehingga kualitas data tergolong rendah atau diragukan kebenarannya (veracity) (Valkanas et al., 2014). Ketiga, volume dan kecepatan (velocity) data membuat pengelola perpustakaan perlu untuk memilih arsitektur perangkat lunak yang sesuai untuk tahap pengumpulan data (Alsubaiee et al, 2015). Keempat, volume big data yang sangat luar biasa akan menjadi tantangan dalam SMA, kemudian masalah bahasa menambah komplikasi lebih lanjut ketika memantau dan menganalisis percakapan media sosial di seluruh dunia, (Fan dan Gordon, 2014). Kelima, media sosial memberikan pendekatan baru untuk mengatasi masalah noisy data dan information-overload dengan pemrosesan informasi berbasis web, akan tetapi perlu menjadi pertimbangan terkait masalah seperti makna yang inkonsistensi dari data, kurangnya struktur data, kualitas data, dan kesulitan dalam mengintegrasikan berbagai jenis data yang ada di media sosial (Zeng et al, 2011).

Dari beberapa hasil penelitian di atas, disimpulkan bahwa harapan untuk menerapkan SMA di perpustakaan yang ada di Indonesia menghadapi beberapa tantangan, diantaranya: (i). Perpustakaan belum menggunakan media sosial dengan optimal. (ii). Bahasa, hal ini akan mempengaruhi jaugkauan media sosial yang dibangun oleh perpustakaan, akan lebih baik menggunakan bahasa internasional, sehingga pengguna yang dijangkau akan lebih luas. (iii) Volume, karena media sosial mengandung data atau metadata dalam jumlah yang sangat besar. (iv). Velocity, kecepatan produksi data dengan keuntungan yang didapat dari menganalisa data secara real time. (v). Variety, social media big 
data seringkali tidak terstruktur atau memiliki struktur khusus. (vi). Veracity, hal ini terkait dengan kebenaran dan kualitas data.

\section{Kesimpulan}

Dari kajian literatur ini dapat disimpulkan bahwa pada umumnya media sosial digunakan sebagai media promosi perpustakaan, seperti mempromosikan koleksi, layanan, kegiatan dan program perpustakaan, serta untuk mempromosikan minat baca. Selain itu, pemanfaatan media sosial terus dikembangkan untuk berbagai kepentingan dalam ruang lingkup perpustakaan, yaitu sebagai media untuk berbagi informasi (information sharing), sebagai media komunikasi, dan media sosial juga telah dimanfaatkan untuk memudahkan proses layanan sirkulasi atau peminjaman. Perpustakaan di Indonesia telah memanfaatkan berbagai jenis media sosial seperti facebook, twitter, RSS feed, youtube, instant messenging, dan flikr. Dari beberapa jenis media sosial tersebut, yang paling banyak digunakan ialah facebook dan twitter.

Jenis-jenis analitik yang bisa digunakan untuk setiap jenis media sosial sangat berbedabeda, dalam penelitian ini hanya memfokuskan pada rancangan analitik untuk facebook dan twitter. Pada facebook, terdapat enam bagian yang perlu diperhatikan dalam proses SMA, diantaranya: overview, likes, reach, visits, posts, dan people. Sedangkan untuk twitter hanya meliputi dua bagian saja yaitu tweet activity dan followers. Tantangan yang dihadapi dalam penerapan SMA untuk perpustakaan di Indonesia ialah penggunaan media sosial yang belum optimal, permasalahan bahasa, volume data, velocity, variety, dan veracity.

Penelitian ini masih dalam ruang lingkup yang terbatas, masih ada sejumlah area tentang SMA yang dapat menjadi bahan kajian untuk ke depannya. Misalnya, peran SMA untuk pengembangan perpustakaan, SMA sebagai intelligent tools, serta bidang lainnya yang dianggap penting untuk dikaji.

\section{Daftar Pustaka}

Alsubaiee, S.,Carey,M.J.,\&Li,C.(2015).LSM-Based Storage and Indexing : an Old Idea with Timely Benefits. Second International ACM Workshop on Managing and Mining Enriched Geo-spatial Data. New York: ACM1-6. http://dx.doi.org/10.1145/2786006. 2786007.
Anna, N. E. V. (2015). Penggunaan Web 2.0 sebagai Media Promosi Perpustakaan Perguruan Tinggi di Indonesia. Record and Library Journal, 1(1), 77-82.

Damayanti, T. E. (2014). Pemanfaatan Twitter sebagai Media Information Sharing di Perpustakaan. Jurnal Universitas Airlangga, 3(2). Diakses dari journal.unair.ac.id/download-fullpaperslna3c10283b4full.pdf.

Fan, W., \& Gordon, M. D. (2014). The Power of Social Media Analytics. Communications of the ACM, 57(6), 74-81. DOI: $10.1145 / 2602574$.

Haryanto. (2016). Pemanfaatan Social Media Network Sebagai Media Komunikasi Komunitas Pustakawan Homogen Dalam Rangkaoptimalisasi Resources Sharing Koleksi Antar Perguruan Tinggi. Pustakaloka, 8(1), 121-130.

Hussain, A. (2015). Adoption of Web 2.0 in Library Associations in the Presence of Social Media. Program: Electronic Library and Information Systems, 49(2), 151-169. DOI 10.1108/PROG-02-2013-0007.

Istiani, P. (2017). Penggunaan Media Sosial oleh Perpustakaan. Libraria, 5(1), 69-86.

Kasiviswanathan, S. P., Melville, P., Banerjee, A., \& Sindhwani, V. (2011). Emerging topic detection using dictionary learning. In Proceedings of the 20th ACM international conference on Information and knowledge management (pp. 745-754). New York: ACM.

https://doi.org/10.1145/2063576.20636 86.

King, D.L. (2015). Managing Your Library's Social Media Channels. American Library Association Journals, 51(1), 26-32.

Kurniasih, N. (2015). Optimalisasi Penggunaan Media Sosial untuk Perpustakaan. Makalah disampaikan pada Seminar Perpustakaan dengan Tema Peningkatan Kompetensi dan Peran Pustakawan di Era Keterbukaan Informasi Publik. Jakarta: Kementrian Perindustrian.

Larasati, A. P. (.n.d). Pemanfaatan Facebook Perpustakaan (Studi Deskriptif Pemanfaatan Jejaring Sosial: Facebook) di Kalangan Anggota Facebook Perpustakaan Kabupaten 
Sidoarjo.

Diakses

dari journal.unair.ac.id/download-fullpapersjurnal\%20Anitya.pdf.

Lovett, J. (2011). Social media metrics secrets. Wiley Publishing: Chichester.

McCallum, I. (2015). Use of Social Media by the Library: Current Practices and Future Opportunities. A White Paper from Taylor \& Francis. The Australian of Library Journal, 64 (2), 161-162. DOI: https://doi.org/10.1080/00049670.2015.10 40364.

Mangold, W.G., \& Faulds, D.J. (2009). Social media: The new hybrid element of the promotion mix. Business Horizons, 52, 357365. doi:10.1016/j.bushor.2009.03.002.

Odewole, M. O. (2017). The Role of Librarian in Using Social Media Tools to Promote the Research Output of HIS/HER Clienteles. Journal of Education and Practice, 8 (27), 109-113.

Pinelli, R., Shapiro, J., Borst, S., \& Storck, P. (2015). Social Media Measurement Guidelines Version 4.1 (draft). Media Rating Council: United States.

Sari, D.P. (2017). Pemanfaatan Media Sosial Sebagai Sarana Promosi Minat Baca Anak Di Perpustakaan Reading Is Fun Jakarta Selatan. Skripsi. UIN Syarif Hidayatullah: Jakarta.

Sen, B.K. (2008). Ranganathan's Five Law's. Annals of Library and Information Studies, 55, 87-90.

Siswanti, A. (2015). Pemanfaatan Layanan Perpanjangan Masa Peminjaman Koleksi Melalui Media Sosial Facebook di Perpustakaan Fakultas Ilmu Sosial dan Ilmu Politik Universitas Gadjah Mada Yogyakarta. Berkala Ilmu Perpustakaan dan Informasi, 11(2), 1-7.

Social Media Research Group. (2016). Using social media for social research: An introduction. Social Media Research Group: United Kingdom.

Sudarsono, B. (2010). Menerapkan Konsep Perpustakaan 2.0. BACA, 31 (1), 1-14.

Sugiyono. (2012). Metode Penelitian Kuantitatif kualitatitf dan R\&D. Alfabeta: Bandung.
Sulistyo-Basuki. (2010). Metode Penelitian. Penaku: Jakarta.

Valkanas, G., Katakis, I., Gunopulos, D., \& Stefanidis, A. (2014). Mining Twitter Data with Resource Constraints. In 2014 IEEE/WIC/ACM International Joint Conferences on Web Intelligence (WI) and Intelligent Agent Technologies (IAT) (pp. 157-164). https://doi.org/10.1109/WIIAT.2014.29.

Wallis, R. (2007). Web 2.0 to Library 2.0 - from Debate to Reality. New Review of Information Networking, 13(1), 53-64.

Zeng, D., Chen, H., Lusch, R., \& Li, S-H. (2011). Social media analytics and intelligence. IEEE Intelligent Systems, 25(6). DOI: 10.1109/MIS.2010.151. 